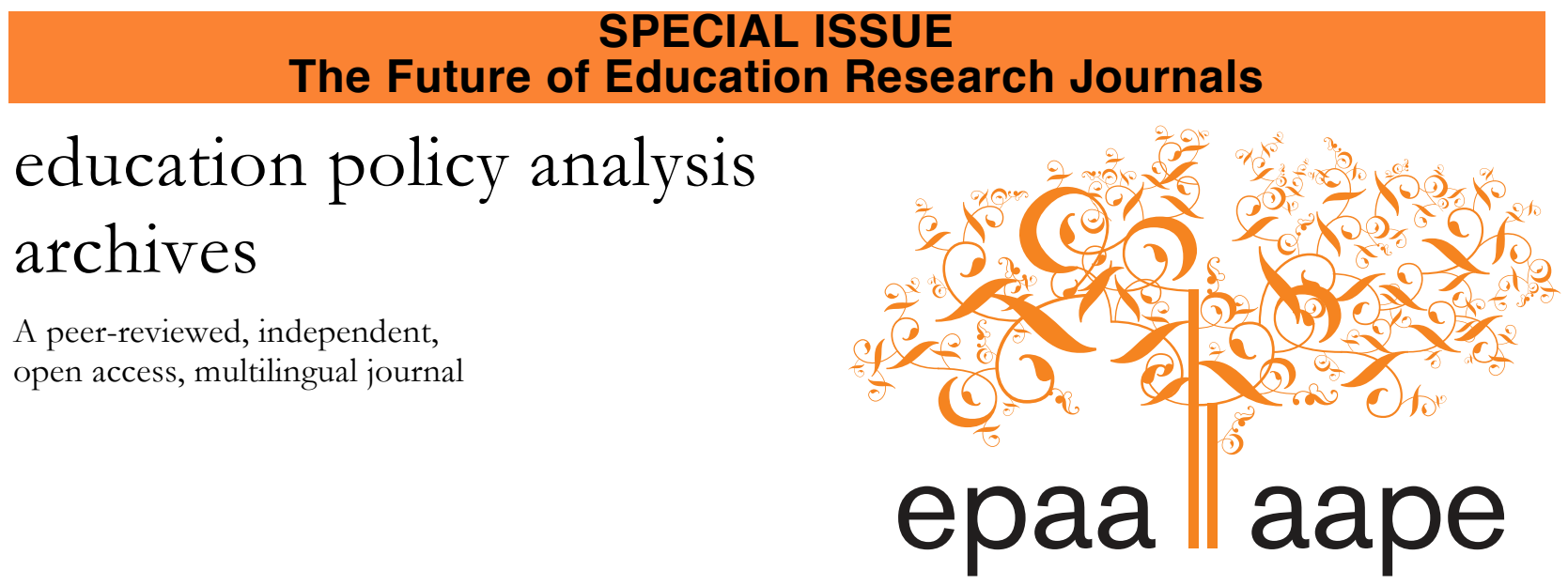

Arizona State University

Volume 22 Number $29 \quad$ May 5 th $2014 \quad$ ISSN 1068-2341

\title{
The SSCI Syndrome in Taiwan's Academia
}

\author{
Chuing Prudence Chou \\ National Chengchi University \\ Taiwan
}

Citation: Chou, C. P. (2014). The SSCI Syndrome in Taiwan's Academia. Education Policy Analysis Archives, 22 (29). http://dx.doi.org/10.14507/epaa.v22n29.2014. This article is part of EPAA/AAPE's Special Issue on The Future of Education Research Journals, Guest Edited by Dr. David Post.

\begin{abstract}
With the global expansion of higher education in the last two decades, the maintenance of academic quality to meet requirements for international competitiveness has become a critical issue for policymakers and universities. In addition, the neoliberal emphasis on the market has increased the competition for global university rankings, and this emphasis continues to have consequences for university autonomy and academic governance. To cope with these challenges, Taiwan has introduced strategies for benchmarking its leading universities. Under the new evaluation system, universities are evaluated by external standards instead of those ensuring academic autonomy or contributions to society. This article details how these recent policy reforms have given rise to a new 'SSCI syndrome', which risks turning faculty members into paper producers rather than public intellectuals. These changes have also impacted students' rights as well as the greater goals of academic development. The article then argues that, as voices from both within and outside of Taiwan's academia have begun to respond to the issue, it begs the question as to whether or not Taiwan can serve as a model for the many other nonEnglish-speaking countries of the academic 'periphery' who are currently confronting similar issues. Given the increasing global pervasiveness of this SSCI syndrome, understanding the effects of policies recently implemented in Taiwan has important
\end{abstract}

Journal website: http://epaa.asu.edu/ojs/

Facebook: /EPAAA

Twitter: @epaa_aape
Manuscript received: 10/9/2013

Revisions received: $1 / 2 / 2014$

Accepted: 2/20/2014 
implications for higher education throughout the world.

Keywords: academic evaluation; globalization; higher education; neoliberalism; publish or perish; SSCI syndrome; Taiwan; university ranking

\section{E1 Síndrome SSCI en la Universidad de Taiwán}

Resumen: Con la expansión global de la educación superior en las últimas dos décadas, el mantenimiento de la calidad académica para cumplir con los requisitos para la competitividad internacional se ha convertido en un tema crítico para los responsables políticos y las universidades. Además, el énfasis neoliberal en el mercado ha aumentado la competencia por los rankings de universidades globales, y este énfasis continúa teniendo consecuencias para la autonomía universitaria y la gobernanza académica. Para hacer frente a estos desafíos, Taiwán ha introducido estrategias para la evaluación comparativa de sus principales universidades. Bajo el nuevo sistema de evaluación, las universidades son evaluadas por normas externas en lugar de las que garantizan la autonomía académica o contribuciones a la sociedad. Este artículo detalla cómo estas reformas políticas recientes han dado lugar a un nuevo "síndrome SSCI", que corre el riesgo de convertir los profesores en productores de "papers" en lugar de los intelectuales públicos. Estos cambios también han afectado a los derechos de los estudiantes, así como los mayores objetivos de desarrollo académico. Luego, el artículo sostiene que, como las voces de dentro y fuera de la academia de Taiwán han comenzado a responder a esta cuestión, se plantea la cuestión de si Taiwan puede o no servir de modelo para muchos otros países de no-hablantes de Inglés y de la "periferia" académica que actualmente están enfrentando problemas similares. Dada la creciente omnipresencia mundial de este síndrome SSCI, la comprensión de los efectos de las políticas aplicadas recientemente en Taiwán tiene importantes implicaciones para la educación superior en todo el mundo.

Palabras clave: evaluación académica; globalización; enseñanza superior; neoliberalismo; publicar o perecer; síndrome SSCI; Taiwán; ranking universitario.

\section{A Síndrome SSCI na Universidade Taiwanesa}

Resumo: Com a expansão global do ensino superior nas últimas duas décadas, a manutenção da qualidade acadêmica para atender às exigências de competitividade internacional tornou-se uma questão crítica para os formuladores de políticas e as universidades. Além disso, a ênfase neoliberal no mercado tem aumentado a concorrência nos rankings universitários mundiais, e essa ênfase continua a ter consequências para a autonomia universitária e governança acadêmica. Para lidar com estes desafios, Taiwan apresentou estratégias para melhorar as suas principais universidades. Sob o novo sistema de avaliação, as universidades são avaliadas por padrões externos, em vez de procurar garantir a autonomia ou acrescentar as contribuições para a sociedade. Este artigo detalha como essas reformas políticas recentes têm dado origem a uma nova "síndrome SSCI ", que corre o risco de transformar os professores em produtores de "papers" em vez de intelectuais públicos. Essas mudanças também impactaram os direitos dos alunos, bem como os maiores objetivos do desenvolvimento acadêmico. O artigo, argumenta que como vozes de dentro e fora da academia de Taiwan começaram a responder à questão , ele levanta a questão de si Taiwan poderia servir como um modelo para muitos outros países não- falantes de Inglês e da "periferia" acadêmica que atualmente estão enfrentando problemas semelhantes. Dada a crescente penetração global desta síndrome SSCI , a 
compreensão dos efeitos das políticas recentemente implementadas em Taiwan tem implicações importantes para o ensino superior em todo o mundo.

Palavras-chave: avaliação acadêmica ; globalização ; ensino superior; neoliberalismo ; publicar ou perecer ; síndrome SSCI ; Taiwan; classificação universidade.

\section{Introduction}

With the rise of neoliberalism in public finance since the 1980s, a great deal of public investment in New Zealand, Australia, Canada, and many countries in Latin America has been linked to the business and market sectors rather than allocated directly to the education sector (Dale, 2001). Furthermore, a sharp reduction in public budgets has influenced not only social values but also educational quality. In particular, as the impacts of globalization have reached higher education, many countries in East Asia have started urging university reforms. Whether in the form of mainland China's 211 project and 985 project, Korea's BK21 program, Taiwan's Five Year Fifty Billion Plan, or Japan's National University Corporation Plan, all have been responses to the process of globalization and increasing demand for competitiveness in academia. Many governments, including Australia, Canada, China, France, Germany, Hong Kong, Japan, Korea, Malaysia, Norway, Singapore, Switzerland, Taiwan, and the U.K., have introduced different strategies for benchmarking their leading universities to facilitate global competitiveness and international visibility (Chou, Lin \& Chiu, 2013).

As a result of these forces as well as its accession to the World Trade Organization (WTO) in 2002, the education system in Taiwan, similar to others in East Asia, has undergone an enormous transformation. Higher education, in particular, has interwoven its path with trends of globalization, localization, the development of information communications technology, and a series of political, social, economic, and managerial changes. As these forces drive policy agendas, these transitions altogether have produced multifaceted influences on higher education in Taiwan, many a result of corresponding policy reforms (Chou \& Ching, 2012).

This article covers two major issues that are byproducts of the forces of globalization, the mainstreaming of the neoliberal economic ideology, and the worldwide trend towards greater international competition in higher education. The first of these are the policy changes resulting from the expansion of the higher education system in Taiwan. Four major areas of policy change are detailed, including governance and the related 'academic drift', the new plans for financing higher education on the national and institutional level, the introduction of an evaluation system for faculty that emphasizes quantitative research performance indicators, and the new flexible salary system intended to reward academics who succeed in this system. The second part then explores a major impact of these policy changes: the emergence of an 'SSCI syndrome' in Taiwanese academia, as professors and researchers are forced to adapt to the new policies. It then discusses some of the local responses attempting to confront the issue and questions whether or not these responses can serve as a model for other countries facing similar situations in higher education, concluding that there are important lessons to be learned as well as significant limitations to using Taiwan as a model of resistance.

\section{Policy Changes}

Prior to 1994, Taiwanese higher education was promoted to serve economic development. The government implemented rather strict control measures over both public and private institutions in terms of establishing new higher education institutes (HEIs); determining their size 
and scale; appointing presidents; regulating admission quotas and curriculum standards; and supervising faculty and student affairs on campus. The addition of new universities was extremely limited thanks to the centralized educational administration being heavily focused on economic development and political stability (Mok, 2014). For example, in 1984 when the per capita income was only US\$4,000, Taiwan had 173,000 university students studying locally, less than one percent of the total population of 19 million (Chou \& Wang, 2012). Higher education remained a means to cultivate elites using a rigorous college entrance exam system to select the best talent in the country.

Beginning in the mid-1990s, higher education in Taiwan experienced a period of unprecedented expansion in response to global competition, a series of domestic political elections from 1996 to 2006, and other social changes. Among these was the Taiwanese government's response to local calls in the form of a social campaign demanding the upgrading and establishment of more high schools and universities. A major goal of this was alleviate the severe and long-existing pressure that resulted from high school and university entrance exams.

As a result of these domestic and international issues, there was an unprecedented higher education expansion in the number of HEIs and students in the following decade. Within the quarter century from 1984 to 2009, the number of universities increased to 148 (51 public and 97 private) and 15 vocational/technical colleges (MOE, 2009). By 2012, there were 162 HEIs, including 120 universities, 28 colleges, and 14 junior colleges (excluding religious colleges, military and police HEIs, and the open universities). As a result, the overall number of students in higher education expanded rapidly as well. During this period, the total student population climbed to nearly 1.36 million, including 3,355 affiliated graduate programs with 215,825 postgraduates enrolled. In 2004, 68.1 percent of Taiwanese 18-year-olds entered college, an enrollment rate almost four times those of mainland China and Hong Kong (Song, 2006). By 2008, higher education students then comprised almost 6 percent of Taiwan's entire population of 23 million, this remarkable demographic change having occurred over the course of two and a half decades (MOE, 2012; Chou \& Ching, 2012; Chou \& Wang, 2012).

\section{Governance and Academic Drift}

Consequently, the government's public spending on higher education became relatively constrained. In response, the Ministry of Education (MOE) launched a series of new governance policies from 1994 to 1996, including revising its Universities Law and setting up the Executive Yuan Education Reform Commission to increase the deregulation, decentralization, democracy, and internationalization of higher education institutions (HEIs). For example, the University Law, as amended in 1994, transformed universities from being under the traditional centralized control of the MOE into more autonomous campus environments, reducing academic and administrative intervention and moving toward more autonomy in terms of admissions, staffing, and tuition policies (Mok, 2014; Chou \& Ching, 2012). In so doing, HEIs were expected to become more competitive and responsive to individual, social and global demands.

The rapid expansion of the higher education system caused some unexpected consequences. The overly rapid upgrade of some vocational/technical colleges into universities changed the nature of HEIs. One side effect was the so-called 'academic drift' of vocational and technological HEIs. This allowed them to convert into 'comprehensive universities' at the expense of their original educational foundation for vocational and technical training, which had formerly been at the core of Taiwan's economic development strategy (Chou, 2008; Hayhoe, 2002). Another impact came from the government's introduction of market competition mechanisms, which accelerated the uneven distribution of resources among public/private and elite/non-elite HEIs and eventually increased social stratification in Taiwan (Chou \& Wang, 2012; Chen \& Chen, 2009). In response to these 
issues, Taiwan's MOE launched several higher education reforms, including the establishment of new university finance plans, the revision of university evaluation systems, and a new system of flexible salaries for public university faculty (MOE, 2009).

\section{Finance Plans}

In the past, public funding, tuition, and fees for Taiwan's public universities were entirely regulated by the MOE, which was their primary source of financing, whereas private HEIs relied mostly on student tuition. For instance, tuition comprised only about 10-20 percent of total expenditures for public universities, whereas the figures were 80-90 percent for private universities. Thus, public institutions relied heavily on government subsidies, while private institutions relied primarily on tuition payments for their operations (Chen \& Chen, 2009).

In order to reduce the funding gap between public and private HEIs, there has been a substantial increase in public assistance to private universities, significantly shrinking the amount of resources devoted to public institutions. The MOE also launched several funding reform schemes to facilitate the accountability and efficiency of public HEIs. Among these, public universities were allowed to set up and regulate their own individual University Funds, donated from the private sector and alumni, beginning in 1999. This policy has changed the relationship between public HEIs and the MOE, effectively transforming them from fully funded agencies into partially subsidized institutions. In addition to the increasing educational parity which took place among regular public HEIs due to lack of sustainable public funding, an inevitable polarization of resource distribution between elite and non-elite public universities has reproduced social stratification in Taiwan since the establishment of the policy (Chen, 2001). Despite these shifts in financing and administration, 60 percent of the total income of public universities still comes from government subsidies, whereas only 20 percent does for private HEIs (Chen \& Chen, 2009).

\section{Evaluation System}

In order to meet the challenge of global competitiveness, standards and effectiveness, Taiwan's University Law was revised in 2003. This revision reiterated that evaluation was to serve as one of the major mechanisms for allocating funding and for assuring the quality of higher education in the future. Based on this law, quality assurance policies have been introduced and reinforced since 2005, and universities have been required to carry out regular self-evaluation in all aspects of teaching, research, and service. The Higher Education Evaluation and Accreditation Council of Taiwan were established accordingly to administer regular external evaluation.

Between 2006 and 2010, the first round of nationwide evaluation was implemented on the departmental, graduate institution, and university level. A total of 1,908 departments and graduate institutions from 79 universities went through this evaluation process, which focused on the quality of universities, departments, and graduates. When reports on the evaluation results were released, they aroused great social controversy and complaints from faculty members and university administrators who were not satisfied with the outcomes being so highly correlated with public funding, institutional prestige, and student recruitment (Wu, 2009).

The second round of national evaluations started in 2011 and will last until 2016. In contrast to the first round, its intended focus is more on evaluating student learning outcomes as well as departments, graduate institutions, and universities from more comprehensive perspectives. These include institutional self-positioning, university governance and management, teaching and learning resources, accountability and social responsibility, sustainable self-improvement, and quality assurance (B.J. Wang, 2010).

In terms of the evaluation of individual faculty members, these national evaluations included the establishment of another internal and external evaluation system intended to monitor faculty 
publication records in various domestic and international databases, such as the SSCI, SCI, and EI. All of these new indicators, which will be discussed later in greater detail, are an effort to conform to international standards and lead to awards, achievements, and contributions to scholarship. Thus, the university evaluation policy is a top-down policy administered by the MOE using indicators developed without consideration of the Taiwanese context. Individual faculty members are thus required by law to submit not only to regular institutional evaluation by the above-mentioned professional associations but also to departmental assessment. Moreover, the evaluation results influence a faculty member's qualifications regarding promotion, changes in salary, sabbatical leave, and extra duties related to teaching and administration. Only recipients of awards at the national or international level can be waived from evaluation.

\section{Flexible Salary System}

The current seniority- and degree-based salary scale in Taiwan has been under criticism for its inadequacy in promoting the necessary competitive environment among faculty that might lead to better teaching and research quality. According to the MOE, the total fixed salary in 2001 for a professor at a public university was between NT $\$ 1,125,000$ and NT $\$ 1,350,000$ (US $\$ 37,500-45,000$ ) before taxes, including a 1.5 month annual award, regardless of discipline. Professors in Hong Kong receive a salary around 3.5 times higher, and in Singapore, 2.5 times higher. The contrast in salaries is even starker when compared with those of their American and European counterparts (Wang, 2009).

A recent migration of university professors away from Taiwan has caused serious concern in the country. Hong Kong, which initiated a new four-year university system, has recruited some top faculty from Taiwan by offering as an incentive two to three times the salary Taiwanese institutions offer (NowNews, 2009). During the last eight years, a total of twenty-seven research fellows have left Academia Sinica, the top research institution in Taiwan, recruited by research institutions in the United States, Europe, and Hong Kong. Prominent faculty from top universities in Taiwan have also relocated to China, Canada, and other competing countries for various reasons (China Post, 2010).

In responding to the global talent hunt and brain drain issues, the MOE, in conjunction with the academic sector, launched in August 2010 a possible solution to facilitate accountability and competition among HEIs and faculty and avoid further brain drain and recruitment shortage of top international research personnel. The flexible salary structure, entitled "recruit and retain special talented personnel implementing a flexible merit-based salary plan", has rewarded academic excellence based on performance and replaced the old fixed-salary system for public university faculty based on seniority and degree (Taipei Times, 2010; Yeh, Cheng, \& Chen, 2009). It is estimated that the new system requires additional funding of between NT $\$ 4$ and 5 billion a year (US\$130-165 million) from the MOE and the National Science Council (NSC). The new plan intends to attract top teaching and research personnel to Taiwan while discouraging faculty from leaving for overseas institutions. It also allows professors' salaries to be subsidized by the MOE's Aim for the Top University Project, known as the "Five-Year Fifty Billion Plan", and Teaching Excellence Award, given in three-year intervals beginning in 2005.

In response to the new flexible salary plan put in place by the government, many critics have expressed concern about the trend of increasing polarization and stratification following the introduction of faculty salaries and benefits based on quantitative indicators, such as journal articles. The system has revealed an unequal distribution of salary increases between faculty in science and the humanities/social sciences, between top and other HEIs, between public and private institutions, and especially between the activities of research and teaching. Complaints about the 
plan target the current oversimplified indicators of performance and meritocracy, which emphasize publication based on pure quantity rather than the quality and essence of performance with respect to teaching and other less readily quantifiable contributions, such as the social impact on society (Chou \& Ching, 2012; Yeh, Cheng, \& Chen, 2009). The underlying justification of policymakers is that Taiwanese faculty are underpaid compared to their international counterparts and that raising flexible income based on research performance will retain the best faculty and attract more top international personnel. However, this notion lacks legitimacy, as it deviates from the local context and overlooks the quid pro quo of the current academic salary structure. For instance, in addition to their base annual salary, university faculty in Taiwan are granted other opportunities to obtain external income as compensation, owing to Taiwan's cultural heritage, which pays high respect to intellectuals and professors. Thus, university faculty (especially those working at public HEIs) also receive more fringe benefits from their consulting services in the public and private sectors, coupled with lifetime medical care and a pension, which are less common among their international competitors (Chou \& Ching, 2012).

\section{SSCI Syndrome}

As the above sections have discussed, policy reforms resulting from globalization, neoliberal restructuring, and an increased emphasis on competition in the international arena have had a tremendous impact on higher education in Taiwan. Each of these policies, including changes in governance, financing, evaluation, and salary structures, has been an attempt to enhance university quality. Today, meritocracy, accountability, and networking among faculty and staff now count for considerably more than they did in the past (Chou, 2008). Yet, in many ways, these reforms have not led to the positive impacts that had been anticipated by policymakers. This is most evident in the emergence of a new phenomenon known as the SSCI syndrome.

\section{Origins}

Citation indices originated as tools for information retrieval, allowing users to trace research from an article by searching for subsequently cited articles and verify topics of interest throughout the years of research literature. Despite their originally intended purpose, researchers over a halfcentury ago discovered that they may be useful beyond this basic function (Price, 1965; Garner, 1967; Garfield, 1994a; Thomson, 2008). These indexes could also, through the tallying of future citations, estimate the influence of that work on the global research community and determine whether a theory had been confirmed, changed, or improved. From this, the role of citation indexes expanded, and they began to be used to evaluate and rank the quality of journals (Garfield, 1972, 1994b).

Today, the academic research quality and impact of individual scholars is commonly measured based on indicators from these citation indexes. Common indicators used derive from the Social Sciences Citation Index (SSCI), the Science Citation Index (SCI), Arts \& Humanities Citation Index (A\&HCI), and the Engineering Index (EI). These citation index databases are owned by Thomson Reuters, a private, for-profit company in the United States. The standards have long been recognized by major English-speaking universities in Australia, Canada, the United States, the United Kingdom, and New Zealand, especially by their science and engineering departments, in quantitatively evaluating the research impact of their faculty.

The past two decades have witnessed increased competition amongst universities for international ranking, in part, because of a demand for this from students, employers, and academics (Williams \& Dyke, 2004). In most cases, the criteria for ranking are based on the above quantitative indicators of research output. In the widely cited yet controversial international ranking of 
universities published by Shanghai Jiao Tong University, for example, the indicators of research quality, namely, articles published in the natural science-focused SCI Expanded and SSCI, have a weight of 20\% (Institute of Higher Education, 2012). As a result, scholars tend to equate the best research products with studies published in the natural sciences and indexed in the SCI and SSCI. Similarly, in "Asia's Best Universities", published by Asia Week, one important indicator of research performance is citations in academic journals tracked by the Journal Citation Index (Asia Week, n.d.). Citation data from the Essential Science Indicators of Thomson Reuters are also used in the Times Higher Education World University Rankings published in the U.K.

In its pursuit of the internationalization of higher education, Taiwan's MOE has built an evaluation system that emphasizes the use of these quantitative indicators. In 2003, the MOE adopted international publication indicators as the evaluation standards for academic performance.

Two ministers of education, Huang Jong-Tsun (2002-2004) and Tu Cheng-sheng (2004-8), presided over the implementation of these new standards. Initially, there was widespread support from government officials in the MOE and NSC as well as academics, particularly those in the natural sciences, economics, and other fields generally favoring the use of quantitative indicators. Prior to this, two anonymous reviewers were given the task of evaluating a scholar's list of publications in completing the performance evaluations. Predominantly based on less quantifiable indicators, this process was seen as lacking objectivity, transparency, and efficiency. While many supported reforms in one way or another, there was also resistance from many in the academic community. As early as 2003, academics had begun to organize in opposition to the new measures. These local responses will be discussed later in greater depth.

The rationales for using international publication indicators stem from the emphasis on university internationalization both in terms of public resource allocation and the facilitation of higher education reform policies, namely, those calling for the establishment of world-class universities. For universities, there are two major driving factors in this pursuit. One is to acquire a superior position versus other higher education institutes in the budgetary competition; the other is to make the university more attractive to prospective students and faculty.

By promoting the use of international citation indexes as indicators for research performance, Taiwanese HEIs are expected to enhance their quality and competitiveness. As a direct response to these new policies, Taiwanese HEIs have set up administrative offices and centers fully devoted to the development of selected key subject areas and to the promotion of "quality" research. The primary performance evaluation process involves counting the actual number of faculty publications in the three databases to determine the final ranking of each college and university. Thus, the academic faculty members of Taiwanese HEIs have been under great pressure from both the government and their institutions to publish internationally in order to acquire SSCI, SCI, A\&HCI, and EI records for the sake of promotion and accreditation (Ching, 2014).

\section{Impacts}

Despite the best efforts of concerned parties to encourage academic excellence in Taiwan, the highly quantitative evaluation indicators have had negative effects. As the emphasis on publications indexed in the citation databases increases, the SSCI syndrome has permeated Taiwanese academia. Under great pressure to publish in indexed, peer-reviewed journals, academics are forced to accept the reality that this pursuit is of paramount importance from both a personal and institutional perspective, and the notion of "publish or perish" prevails.

Publication figures are used as major criteria in the university evaluation system, approval of research grants, university social rankings, the granting of tenure, promotion, and even the awarding of government funding (Kao \& Pao, 2009). Not surprisingly, these assessment standards have led 
Taiwanese scholars to narrow their focus, emphasizing publication in international journals, in English instead of Chinese, and in subjects preferred by international journals rather than those addressing local needs (Chen \& Qian, 2004).

Moreover, publication expectations are not uniform across all disciplines. Moreover, the distinctive characteristics of particular academic subjects are largely ignored, and professors of certain departments who feel that they are being subjected to unfair competition have complained. The goal of such evaluation is to improve research quality; however, the nature of the subject and the effect of the social and cultural context must also be considered (IREG, 2010). In the evaluation of scholarship in terms of SSCI and SCI academic publication, more than a single set of standards should be applied to highlight the strengths and weaknesses of published scholarly work. For example, the "Five Year, Fifty Billion" Plan, launched in 2005 and sponsored again in 2011, is a program aimed at allocating funds based on competition (Chou \& Ching, 2012; Chang \& Ho, 2007). The financial resources from the plan go to selected leading universities, such as National Taiwan University (NTU), which offers more natural science courses than humanities and social science courses. These universities thus end up with rich research facilities and adequate financial assistance in an era of public budget constraints in Taiwan. Consequently, other universities are neglected. The social science-oriented National Chengchi University (NCCU), for one, has felt the impacts of these reforms, receiving the least amount of funding.

Thus, the flexible salary system has a lower value for faculty and universities in the humanities and social sciences, who publish less in SSCI and SCI than their counterparts in the natural sciences. Faculty members from two prestigious national universities with comparable student populations in Taiwan are treated differently according to the current rules of the game, in which only half of the faculty from the humanities and social sciences are granted this award, which is 50 percent less than that of their competitors with a science background. Increasing cultural and reward gaps have worsened the existing unequal distribution of resources between the sciences and the social sciences as a result of the government's new scheme. According to Ye (2004), the social sciences and humanities, whose major forms of publication are books rather than journal articles, are concerned mostly with local and national issues. These fields also have historical and cultural boundaries. Consequently, the articles can be difficult to translate into English to break cultural barriers and address social concerns.

The academic incentive pay system also makes it far more complex and difficult to evaluate performance and accountability than in the past. As is the case with other professions, economic incentive is not the only factor that motivates faculty to accomplish goals and excel. Differences in level of performance in academia are large and contingent upon circumstances. According to research (Lin, 2009), any tangible reward in the form of recognition, coupled with monetary rewards and promotions, will possibly yield increased productivity. However, it will also require a strong intuitive appeal, such as self-motivation and dignity through achievement. Many academic faculty prefer the idea of the university paying them indirectly by improving the whole academic structure and environment rather than setting a flexible salary that only rewards "star researchers", while the

majority of faculty are devalued when they assume more responsibility for teaching and community service (Lin, 2009).

\section{Local Responses}

Due to the rise of the SSCI syndrome and the trends discussed in the preceding sections, many have come to question the reforms. The emphasis on quantitative evaluation indicators has aroused controversy, and scholars of all disciplines are asking what can be done to prevent this continuing over-emphasis on SSCI publication in higher education policy. Reactions from the 
humanities and social sciences, fields in which research accomplishments are overlooked by the current paper-driven orientation, have been particularly strong.

As early as 2003, when the MOE and NSC were pushing to implement the new performance evaluation indicators, academics had already begun to organize in response to the reforms. After holding a series of conferences, a book entitled Globalization and Knowledge Production: Reflections on Taiwan's Academic Evaluations was published by a group of academics in the social sciences (Reflections Meeting Working Group, 2004). While these early efforts increased awareness about the potential negative impacts of using international publication indicators, they were ultimately unsuccessful in altering the course of the reforms.

As research is increasingly geared toward publication rather than public benefit, a debate has begun on whether these educational policies' performance indicators overly emphasize global standards and whether international benchmarks are dominated by Western (particularly, American) tradition and practice (Mok \& Tan, 2004; Lai, 2004; Wang, 2014). Unlike native English-speaking countries and other societies with historically high levels of English proficiency, English is a foreign language to the vast majority of researchers in Taiwan. In order to participate and survive in the international academic community, non-native English speakers need to strive to overcome language obstacles in order to publish in international journals. The global pervasiveness of the norm of English as the lingua franca often ignores different voices from the peripheral, or non-English speaking, world (Liu, 2014).

Nevertheless, more and more faculty members are falling victim to the SSCI syndrome and the competitive winner-takes-all reward system that emphasizes research more than teaching and other contributions to society. In fact, faculty members across Taiwan have lost their jobs due to their failure to satisfy research performance requirements or refusal to submit to an evaluation. One of the most controversial cases in Taiwan concerns a professor from a prestigious national university who was forced to leave due to his refusal to apply for self-evaluation. Despite having received two outstanding teaching awards on campus and being recognized as an exceptional professor by his students, he could not succeed in today's academia. He had published an insufficient number of research articles as well as failed to fulfill the university's requirement for self-evaluation. Thus, his case was vetoed twice, both by the university and the MOE grievance committee. Nevertheless, his termination of employment generated nationwide student support (Wang, 2010).

In order to publicize the heated debates over SSCI-related issues, a group of Taiwanese university faculty initiated an online petition for collective action in November 2010. The petition had two purposes: firstly, to demand that Taiwan's government discontinue their policies codifying indexed journals as the primary indicators for university evaluation and funding purposes and adopt alternative evaluation policies. The petition also urged public funding agencies to expand both the quantity and the variety of academic journals in the international and domestic journal citation databases and give concordant weights to publications in the humanities and social sciences. The petition, on the whole, intended to protest the reforms with social action, locally and globally, encouraging Taiwan's government and university authorities to include diverse and reliable evaluation indicators in recognizing research of different nature and disciplines while creating culturally responsive evaluation criteria for social sciences and humanities (Chou, Lin, \& Chiu, 2013).

Since 2010, the petition has gained support from academics and civil society, including endorsement by nearly 3,000 petitioners, $85 \%$ of whom worked in the humanities and social sciences and 10\% in science-related fields. In addition, the major demands of the petition have been echoed in various public forums and public-sponsored research findings. Moreover, the debates over SSCI have continued to attract public awareness via national news coverage. Not until mid- 
2012, did the top government officials in Taiwan responsible for higher education policy, agree for the first time to review the SSCI issue. Thereafter, the government did make revisions to their proSSCI funding policies and evaluation guidelines (NCCU Teachers' Association, 2012). Despite these minor policy changes intended to address the demands of academics, the SSCI syndrome continues to dominate the overall structure and reward system in Taiwanese academia.

\section{Going Global?}

Taiwanese scholars have come to understand that it is of great importance to invite more public discourse and social action out of this issue in search for alternative solutions to enhance competitiveness of Taiwan's higher education system. At the same time, professors have begun to ask whether the case of Taiwan can serve as a testimony and lesson for other higher education systems in the non-English-speaking world. Despite the bibliographic purpose of citation indexes, university administrators and public funding agencies continue to employ them when hiring, promoting, and funding faculty (Kokko and Sutherland, 1999; Bauer and Bakkalbasi, 2005). Indeed, this phenomenon is not limited to HEIs in Taiwan. There is increasing skepticism about the use of these tools to evaluate research performance (Ackermann, 2001). According to the founder of Thomson Reuters (Garfield, 1994b), a more reliable evaluation system should involve actually reading each article for its quality, although the problem of judgment between peer reviewers then arises. While citation criteria can be used as assessment measures of the impact of scientific scholarship (Lawani \& Bayer, 1983), some studies still contend that ISI citation indexes are far from objective, that determinations of the influence of ISI journals are not reliable, and that the word "global" stretches the truth about the master journal list (Cruz, 2007). Journal articles in the SSCI, SCIE, A\&HCI, and EI are written mostly in English. Among the 96 articles listed in the sociology section of the SSCI, for example, 45 are from the United States, 27 from the United Kingdom, four from Germany, and two from France, all of which are written in English. Such statistics are discouraging to non-English researchers in the humanities and social sciences wishing to submit their articles to influential journals. Both the language barrier and cultural irrelevancy of these journals is a major factor in these considerations.

In Taiwanese attempts to increase the global awareness of the SSCI syndrome, efforts have been made to catalyze international collective responses. One notable example of this has been a book co-authored by colleagues from Hong Kong, Malaysia, Taiwan, and the U.S., entitled The SSCI Syndrome in Higher Education: A Local or Global Phenomenon (Chou, 2014). This endeavor begins with empirical research on Taiwan that critically examines how academics evaluate the impact of the recent university governance reforms on institutional autonomy and the academic profession, concluding that the academia in Taiwan and Asia, as a whole, is continually impacted by its strong managerial governance (Mok, 2014).

Moreover, the rationale for a quantitative academic evaluation system lies in the need to control a restless academia in the process of rampant and factional democratization in Taiwan after the 1990s. Compared with their counterparts in Japan and the U.S., Taiwanese academia has been characterized by factions and lacked the consensus of building systematic and integrated types of research capabilities with local and global features. Nevertheless, using citation indexes for academic evaluation neglects the issue of how Taiwanese academic research can become more attractive to international audiences while being reoriented towards solving local issues at the same time (Wang, 2014).

As with other countries, education policy and programs in Taiwan have been myopic, refraining from any long-term focus due to the frequency of political elections, which lead to changes of administration locally and nationally. Consequently, quantitative criteria, justified as being 
in the name of fairness and objectivity, are widely employed. However, this approach conceals the subjective rationale of those who judge them. The ideology of "winners take all" has resulted in a concentration of resources among top-publication research groups and universities, widening the social gap between classes. Higher education policies such as the Plan to Develop First-class Universities and Top-level Research Centers have negatively impacted the nature of academic research and educational equity (Chan and Lee, 2014).

Furthermore, it has been demonstrated that the SSCI syndrome has a discriminatory impact on local publication while reinforcing the academic hegemony of native English-speaking countries. The current academic reward policy in Taiwan has promoted utilitarianism, academic capitalism and hierarchy that aggravate the social injustice and inequity (Su, 2014). Faculty and student perceptions indicate that the continuous influence of ISI has dominated the majority of academic settings and activities in Taiwan (Ching, 2014). Undoubtedly, this phenomenon is not unique to Taiwan, though it must be noted that, at least when compared to China, where economic and academic resources are less transparent and accessible, Taiwan's fairly even distribution of resources is quite distinct (Liu, 2014). Nevertheless, there may be certain lessons to be gleaned from Taiwan's experiences in confronting the challenges presented by the SSCI syndrome.

One possible solution to the SSCI syndrome that has been proposed in the field of education is the creation of a citation database for international education journals specifically focusing on the Taiwan context. The proponents of this solution argue that there should be a balance in the importance given to the impact factors from local and international citation indexes (Cheng, Jacob, and Yang, 2014).

On the whole, the SSCI syndrome in Taiwan reinforces the privileged status of English in the international academic community. Ironically, while the vast majority of the Taiwanese researchers are non-English speakers, scholars in Taiwan have been encouraged by government and university to self-align with the privileged discourse and participate in the international academic community regardless of discipline and academic background. Taiwan's higher education policymakers still believe that the legitimacy of a hegemonic English-based knowledge industry will enable Taiwan's academia to bring about a diverse voice from the periphery and lead to a paradigm shift coming from within Taiwan's academic community (Wu \& Bristow, 2014; Liu, 2014). Nevertheless, unlike the natural sciences, the humanities and social sciences deal with more social and cultural issues. Thus, the latter are expected to foster a culture of social responsibility via culturally-responsive and socially-relevant research whose content and findings should meet the needs of local people and community. Therefore, the establishment of culturally-responsive evaluation criteria for social sciences and humanities are essential not only for the livelihood of academics in Taiwan and elsewhere but also for their potential contributions to the greater social good.

\section{Conclusion}

With the expansion of Taiwan's higher education system in the last two decades, the maintenance of quality to meet the requirements for international competitiveness has become a key concern for policymakers. This article has detailed how, since the early 2000s, the MOE has introduced a series of higher education policy reforms to enhance academic excellence in universities and established a formal university evaluation policy to improve the competitiveness and international visibility of Taiwanese universities. In so doing, the government has codified a clear link between evaluation results and public funding allocation. Faculty research performance has been prioritized as the key indicator for gaining public funding as well as 
academic and social prestige. University evaluation has taken on a highly quantitative dimension, which rewards academics based on factors associated with the number of articles published in journals indexed by SSCI and other indexes. The emphasis on quantitative evaluation indicators has resulted in mixed feelings and reactions amongst members of academic disciplines nationwide. Particularly for academics in humanities and social sciences, many of their research accomplishments have been undervalued or neglected by the dominant emphasis on quantitative indicators. In detailing the momentous impacts that these policy changes have had on academia and the responses that have resulted from them, this article has discussed some of the potential solutions to this SSCI syndrome that have been proposed in Taiwan. While it has its limitations and the process remains ongoing, the Taiwanese experience may offer valuable lessons for the many other non-English-speaking countries on the academic "periphery" that are currently undergoing similar challenges in academia.

\section{References}

Ackermann, E. G. (2001). Developing comparative bibliometric indicators for evaluating the research performance of four academic nutrition departments, 1992-1996: An exploratory study. Knoxville, TN: University of Tennessee.

Anderson, M. S., Ronning, E. A., Vries, R. D., \& Martinson, B. C. (2007). The perverse effects of competition on scientists' work and relationships. Science and Engineering Ethics, 13, 437-461. http://dx.doi.org/10.1007/s11948-007-9042-5

Asia Week. (2000). Asia's best universities 2000. CNN. Retrieved from http://edition.cnn.com/ASIANOW/asiaweek/features/universities2000/index.html

Bauer, K., \& Bakkalbasi, N. (2005, September). An examination of citation counts in a new scholarly communication environment. D-Lib Magazine, 11. http://dx.doi.org/10.1045/september2005-bauer

Boyer, E. L. (1990). Scholarship reconsidered: Priorities of the professoriate. Princeton, NJ: The Carnegie Foundation for the Advancement of Teaching.

Chambers, C. (2004). Technological advancement, learning, and the adoption of new technology. European Journal of Operational Research, 152(1), 226-247. http://dx.doi.org/10.1016/S0377-2217(02)00651-3

Chan, J. C.-Y. \& Lee, C.-N. (2014). A difficult situation of higher education in Taiwan. In Chou, C.P. (ed.). The SSCI syndrome in higher education: A local or global phenomenon. Netherlands: Sense Publishers.

Chang, K. W., \& Ho, M. S. (2007). Half-hearted neoliberal reform: Analyzing Taiwan's college tuition policy and controversy. Education and Social Studies, 12, 73-112.

Chen, L.-C. \& Chen, S.-T. (2009). An analysis of our universities' financial structures and what it reveals about tuition and fee policy formulation. Presented at the Dialogue on Education Research and Education Policy International Academic Symposium, November 20-21, Taipei, Taiwan Normal University.

Chen, K. S., \& Qian, Y. X. (2004). Academic production under the neo-liberalism globalization (in Chinese). Paper presented at the Reflecting on Taiwan's Higher Education Academic Evaluation Conference. International Plenary Hall, National Library, Taipei, Taiwan.

Chen, L.-J. (2001). The effect of public university fund policy in Taiwan. Education Policy Forum, 4(1), 118-166. 
Cheng, K. S. Y., Jacob, W. J. \& Yang, S.-K. (2014). Reflections from the Social Science Citation Index (SSCI) and its influence on education research in Taiwan. In C. P. Chou (Ed.), The SSCI syndrome in higher education: A local or global phenomenon. Netherlands: Sense Publishers.

China Post (2010, January 24). Gov't mulls professor salary raise. China Post. Retrieved from http://www.chinapost.com.tw/taiwan/national/national$\% 20$ news /2010/01/24/242077/Govt-mulls.htm

Ching, G. S. (2014). ISI perceptions and hard facts: An empirical study from Taiwan. In C. P. Chou (Ed.), The SSCI syndrome in higher education: A local or global phenomenon. Netherlands: Sense Publishers.

Chou, C. P. (2008). The impact of neo-liberalism on Taiwanese higher education. In D. Baker \& A. W. Wiseman (Eds.), The worldwide transformation of higher education (pp. 297-312. Bingley, U.K.: Jai.

Chou, C. P., \& Ching, G. S. (2012). Taiwan education at the crossroad: When globalization meets localization. New York: Palgrave Macmillan. http://dx.doi.org/10.1057/9780230120143

Chou, C. P., Lin, H. F. \& Chiu, Y. J. (2013). The impact of SSCI and SCI on Taiwan's academy: An outcry for fair play. Asia Pacific Education Review, 14, 23-31. http:/ / dx.doi.org/10.1007/s12564-013-9245-1

Chou, C. P. \& Wang, L. T. (2012). Who benefits from the popularization of higher education in Taiwan?. Chinese Education and Society, 45(5-6), 8-20.

Cruz, I. (2007). Challenging ISI Thomson Scientifics' journal citation reports: Deconstructing “objective," “impact," and "global." Vancouver, Canada: PKP Scholarly Publishing. Retrieved from http://scholarlypublishing.blogspot.com

Dale, R. (2001). Constructing a long spoon for comparative education: Charting the career of the New Zealand model. Comparative Education, 37(4), 493-501. http://dx.doi.org/10.1080/03050060120091274

Dirks, A. L. (1998). The new definition of scholarship: How will it change the professoriate? Retrieved from http://webhost.bridgew.edu/adirks/ald/papers/skolar.htm

Flowerdew, J. (1999). Problems in writing for scholarly publication in English: The case of Hong Kong. Journal of Second Language Writing, 8(3), 243-264. http:/ /dx.doi.org/10.1016/S1060-3743(99)80116-7

Garfield, E. (1972). Citation analysis as a tool in journal evaluation: Journals can be ranked by frequency and impact of citations for science policy studies. Science, 178(4060), 471-479. http:/ / dx.doi.org/10.1126/science.178.4060.471

Garfield, E. (1994a). The concept of citation indexing: A unique and innovative tool for navigating the research literature. Retrieved from http://wokinfo.com/essays/conceptof-citation-indexing/

Garfield, E. (1994b). Linking literatures: An intriguing use of the citation index. Retrieved from http://wokinfo.com/essays/linking-literatures/

Garner, R. (1967). A computer oriented, graph theoretic analysis of citation index structures. Drexel Press. Retrieved from http://www.garfield.library.upenn.edu/rgarner.pdf

Hayhoe, R. (2002). Teacher education and the university: A comparative analysis with implications for Hong Kong. Teaching Education, 13(1), 5-23. http:/ /dx.doi.org/10.1080/1047210120128555

Huang, A. H. M. (2009). Science as ideology: SSCI, TSSCI and the evaluation system of social sciences in Taiwan. Inter-Asia Cultural Studies, 10(2), 282-291. http:/ / dx.doi.org/10.1080/14649370902823413 
Huang, A. H. M. (2004). SSCI, TSSCI and Taiwan social science evaluation system (in Chinese). Paper presented at the Reflecting on Taiwan's Higher Education Academic Evaluation Conference, International Plenary Hall, National Library, Taipei, Taiwan.

Institute of Higher Education, Shanghai Jiao Tong University (ARWU). (2012). World ranking methodology. Retrieved from http://www.shanghairanking.com/ARWU-Methodology2012.html

IREG. (2010). The academic rankings: From popularity to reliability and relevance. Retrieved from http://www.ireg-observatory.org/pdf/abstracts_and_speakers.pdf

Keith, B. (1999). The institutional context of departmental prestige in American higher education. American Educational Research Journal, 36(6), 409-445. http:/ / dx.doi.org/10.3102/00028312036003409

Kao, C., \& Pao, H. L. (2009). An evaluation of research performance in management of 168 Taiwan universities. Scientometrics, 78(2), 261-277. http://dx.doi.org/10.1007/s11192-0071906-6

Kokko, H., \& Sutherland, W. J. (1999). What do impact factors tell us? Trends in Ecology \& Evolution, 14(10), 382-384. http://dx.doi.org/10.1016/S0169-5347(99)01711-5

Lai, D. M. (2004). Quantitative indexes are not the panacea of academic evaluation (in Chinese). Paper presented at the Reflecting on Taiwan's Higher Education Academic Evaluation Conference, International Plenary Hall, National Library, Taipei, Taiwan.

Lawani, S. M., \& Bayer, A. E. (1983). Validity of citation criteria for assessing the influence of scientific publications: New evidence with peer assessment. Journal of the American Society for Information Science, 34(1), 59-66. http://dx.doi.org/10.1002/asi.4630340109

Lin, S.-D. (2009). A study on the flexible salary compensation system for national university professors in Taiwan. Unpublished master's thesis. Retrieved from http:// nccur.lib.nccu.edu.tw/handle/140.119/34772

Liu, Y.-J. (2014). Problems, strategies, and impact of SSCI publication in English: Perceptions and negotiations of Taiwanese researchers. In C. P. Chou (Ed.), The SSCI syndrome in higher education: A local or global phenomenon. Netherlands: Sense Publishers.

Ministry of Education (2009). Higher education for excellence. Taipei: MOE.

Ministry of Education (2012). Education statistics. Taipei: MOE. Retrieved from https://stats.moe.gov.tw/files/ebook/Education_Statistics/102/102edu.pdf

Mok, K. H. (2014). Promoting the global university in Taiwan: University governance reforms and academic reflections. In C. P. Chou (Ed.), The SSCI syndrome in higher education: A local or global phenomenon. Netherlands: Sense Publishers.

Mok, K. H., \& Tan, J. (2004). Globalization and marketization in education: A comparative analysis of Hong Kong and Singapore. Cheltenham, U.K.: Edward Elgar Publishers. Retrieved from http://www.ireg-observatory.org/pdf/abstracts_and_speakers.pdf

Morris, P. (1996). Asia's four little tigers: A comparison of the role of education in their development. Comparative Education, 32(1). 95-109. http://dx.doi.org/10.1080/03050069628948

NowNews (2009). High salary in Hong Kong. Taipei. NowNews Network. Retrieved from http://www.nownews.com

NCCU Teachers' Association. (2012). Petition statement. Taiwan Competitiveness Forum. Retrieved from http://memo.cgu.edu.tw/yunju/CGUWeb/NCCUEdu2010/HomeAgainstSSCI.htm 
Price, D. J. S. (1965). Networks of scientific papers: The pattern of bibliographic references indicates the nature of the scientific research front. Science, 149(3683), 510-515. http:/ /dx.doi.org/10.1126/science.149.3683.510

Palmquist, R. A. (2001). Bibliometrics. Austin, TX: University of Texas, Austin. Retrieved from http://www.gslis.utexas.edu

Reflections Meeting Working Group. (2004). Globalization and knowledge production: Reflections on Taiwan's academic evaluations. Taiwan Society Research Forum 04. Retrieved from http://taishe.shu.edu.tw/book_forum_04.html

Su, S.-W. (2014). To be or not to be: Impacts of "I" idolization. In C. P. Chou (Ed.), The SSCI syndrome in higher education: A local or global phenomenon. Netherlands: Sense Publishers.

Shin, J. C. \& Harman, G. (2009). New challenges for higher education: Global and Asia-Pacific perspectives. Asia Pacific Education Review, 10(1), 1-13. http://dx.doi.org/10.1007/s12564009-9011-6

Song, P.-C. (2006, October). Comparative assessment of 65 universities in greater China: Taiwan's teachers superior; research strong in China and Hong Kong. Global Views Montbly.

Taipei Times. (2010, January 1). Academic sector proposes flexible salary for experts. Taipei Times. Retrieved from http://www.taipeitimes.com

Thelwall, M., Vaughan, L., Cothey, V., Li, X. M., \& Smith, A. G. (2003). Which academic subjects have most online impact? A pilot study and a new classification process. Online Information Review, 27(5), 333-343. http://dx.doi.org/10.1108/14684520310502298

Thomson, R. (2008). Web of science. New York: Thomson Reuters. Retrieved from http://scientific.thomson.com/products/wos/

Wang, H. H. (2014). The political economy of quantitative indexes for measuring academic performance. In C. P. Chou (Ed.), The SSCI syndrome in higher education: A local or global phenomenon. Netherlands: Sense Publishers.

Wang, B.-J. (2010). University evaluation based on the whole school evaluation approach. Bimonthly Evaluation, 23. Retrieved from http://epaper.heeact.edu.tw/archive/2010/01/01/2282.aspx

Wang, T.-L. (2009). Salary of assistant professor is lower than those who teach in primary/junior high school. Taipei: United Daily News Group. Retrieved from http://mag.udn.com

Wang, W.-L. (2010). It is about time for university faculty to be alert thanks to the strict evaluation system. United News. Retrieved from http://mag.udn.com/mag/campus/storypage.jsp?f_ART_ID $=279045$

Williams, R., \& Dyke, N. V. (2004). The international standing of Australian universities. Melbourne Institute. Retrieved from http://www.melbourneinstitute.com/downloads/reports/ExecSumm.pdf

Wu, C. C. (2009). Higher education expansion in Taiwan: The problems faced. Taipei: National Taiwan Normal University. Retrieved from http://cve.ntnu.edu.tw

Wu, L.-Y. \& Bristow, A. (2014). Perishing Confucius: An analysis of a rupture point in the discourse of Taiwanese "New Higher Education." In C. P. Chou (Ed.), The SSCI syndrome in higher education: A local or global phenomenon. Netherlands: Sense Publishers.

Ye, Q. Z. (2004). The lack of the sense of social practice: The myth of criterion-based evaluation (In Chinese). Paper presented at the Reflecting on Taiwan's Higher Education Academic Evaluation Conference, International Plenary Hall, National Library, Taipei, Taiwan. 
Yeh, W.-Y., Cheng, Y., and Chen, C. J. (2009). Social patterns of pay systems and their associations with psychosocial job characteristics and burnout among paid employees in Taiwan. Social Science \& Medicine, 68(8), 1407-1415.

http://dx.doi.org/10.1016/j.socscimed.2009.01.031 


\section{About the Author}

Chuing Prudence Chou

National Chengchi University

iaezcpc2007@gmail.com

Chuing Prudence Chou is Professor in the Department of Education at National Chengchi

University (NCCU), Taiwan. She has been a Fulbright Scholar (2006-07, and 2012-13) visiting

Harvard University and University of Miami. As a part-time professor at Akita International

University (AIU) and Tohoku University, Japan, Chou demonstrated her specialty in applying a new framework as "cross-straitization" in dealing with conflicts and peace among rivalry countries. Her research interests include educational exchanges between China and Taiwan, and education reforms under the influence of neo-liberalism, globalization and localization. Her book entitled "Taiwan Education at the Crossroad" (Palgrave Macmillan, 2012) details Taiwan's most recent education reform policy in the era of globalization. (iaezcpc@nccu.edu.tw;

http://www3.nccu.edu.tw/ iaezcpc/en/index.html)

\section{About the Guest Editor}

David Post

profdavidpost@gmail.com

Post@psu.edu

David Post is Senior Policy Analyst with the Global Monitoring Report of Education For All, and is currently based at UNESCO in Paris. He also is Professor of Comparative and International Education who is currently on leave from Penn State University in the USA. He has researched and published about educational stratification, about child labor issues, as well as the politics of educational mobilization. He also investigates the impact of concurrent employment on student academic achievement. He has been a visiting professor at the Colegio de México, at the Facultad Latinoamericana de Ciencias Sociales, and at the Hong Kong University of Science and Technology. Finally, David served for ten years as editor of Comparative Education Review, where he became concerned about the commodification of scholarship and the possible responses to it by intellectuals, for example through peer-reviewed, open access publication of studies like those in this special issue. Last year, the EEPA printed the Spanish version of his commentary, "Los Rankings Académicos." http://epaa.asu.edu/ojs/article/view/1347

\section{SPECIAL ISSUE The Future of Education Research Journals education policy analysis archives}

Volume 22 Number $29 \quad$ May 5 $5^{\text {th }}, 2014$ ISSN 1068-2341 


\section{(c)}

SOMEREIGHISRESERVED Readers are free to copy, display, and distribute this article, as long as the work is attributed to the author(s) and Education Policy Analysis Archives, it is distributed for noncommercial purposes only, and no alteration or transformation is made in the work. More details of this Creative Commons license are available at http://creativecommons.org/licenses/by-nc-sa/3.0/. All other uses must be approved by the author(s) or EPAA. EPAA is published by the Mary Lou Fulton Institute and Graduate School of Education at Arizona State University Articles are indexed in CIRC (Clasificación Integrada de Revistas Científicas, Spain), DIALNET (Spain), Directory of Open Access Journals, EBSCO Education Research Complete, ERIC, Education Full Text (H.W. Wilson), QUALIS A2 (Brazil), SCImago Journal Rank; SCOPUS, SOCOLAR (China).

Please contribute commentaries at http://epaa.info/wordpress/ and send errata notes to Gustavo E. Fischman fischman@asu.edu

Join EPAA's Facebook community at https://www.facebook.com/EPAAAAPE and Twitter feed@epaa_aape. 


\section{education policy analysis archives editorial board}

Editor Gustavo E. Fischman (Arizona State University)
Associate Editors: Audrey Amrein-Beardsley (Arizona State University), Rick Mintrop, (University of California, Berkeley)

Jeanne M. Powers (Arizona State University)

Jessica Allen University of Colorado, Boulder

Gary Anderson New York University

Michael W. Apple University of Wisconsin, Madison

Angela Arzubiaga Arizona State University

David C. Berliner Arizona State University

Robert Bickel Marshall University

Henry Braun Boston College

Eric Camburn University of Wisconsin, Madison

Wendy C. Chi* University of Colorado, Boulder

Casey Cobb University of Connecticut

Arnold Danzig Arizona State University

Antonia Darder University of Illinois, UrbanaChampaign

Linda Darling-Hammond Stanford University

Chad d'Entremont Strategies for Children

John Diamond Harvard University

Tara Donahue Learning Point Associates

Sherman Dorn University of South Florida

Christopher Joseph Frey Bowling Green State University

Melissa Lynn Freeman* Adams State College

Amy Garrett Dikkers University of Minnesota

Gene V Glass Arizona State University

Ronald Glass University of California, Santa Cruz

Harvey Goldstein Bristol University

Jacob P. K. Gross Indiana University

Eric M. Haas WestEd

Kimberly Joy Howard* University of Southern California

Aimee Howley Ohio University

Craig Howley Ohio University

Steve Klees University of Maryland

Jaekyung Lee SUNY Buffalo
Christopher Lubienski University of Illinois, UrbanaChampaign

Sarah Lubienski University of Illinois, UrbanaChampaign

Samuel R. Lucas University of California, Berkeley

Maria Martinez-Coslo University of Texas, Arlington

William Mathis University of Colorado, Boulder

Tristan McCowan Institute of Education, London

Heinrich Mintrop University of California, Berkeley

Michele S. Moses University of Colorado, Boulder

Julianne Moss University of Melbourne

Sharon Nichols University of Texas, San Antonio

Noga O'Connor University of Iowa

João Paraskveva University of Massachusetts, Dartmouth

Laurence Parker University of Illinois, UrbanaChampaign

Susan L. Robertson Bristol University

John Rogers University of California, Los Angeles

A. G. Rud Purdue University

Felicia C. Sanders The Pennsylvania State University

Janelle Scott University of California, Berkeley

Kimberly Scott Arizona State University

Dorothy Shipps Baruch College/CUNY

Maria Teresa Tatto Michigan State University

Larisa Warhol University of Connecticut

Cally Waite Social Science Research Council

John Weathers University of Colorado, Colorado Springs

Kevin Welner University of Colorado, Boulder

Ed Wiley University of Colorado, Boulder

Terrence G. Wiley Arizona State University

John Willinsky Stanford University

Kyo Yamashiro University of California, Los Angeles

* Members of the New Scholars Board 


\section{archivos analíticos de políticas educativas consejo editorial}

Editor: Gustavo E. Fischman (Arizona State University)

Editores. Asociados Alejandro Canales (UNAM) y Jesús Romero Morante (Universidad de Cantabria)

Armando Alcántara Santuario Instituto de Investigaciones sobre la Universidad y la Educación, UNAM México

Claudio Almonacid Universidad Metropolitana de Ciencias de la Educación, Chile

Pilar Arnaiz Sánchez Universidad de Murcia, España

Xavier Besalú Costa Universitat de Girona, España Jose Joaquin Brunner Universidad Diego Portales, Chile

Damián Canales Sánchez Instituto Nacional para la Evaluación de la Educación, México

María Caridad García Universidad Católica del Norte, Chile

Raimundo Cuesta Fernández IES Fray Luis de León, España

Marco Antonio Delgado Fuentes Universidad Iberoamericana, México

Inés Dussel FLACSO, Argentina

Rafael Feito Alonso Universidad Complutense de Madrid, España

Pedro Flores Crespo Universidad Iberoamericana, México

Verónica García Martínez Universidad Juárez Autónoma de Tabasco, México

Francisco F. García Pérez Universidad de Sevilla, España

Edna Luna Serrano Universidad Autónoma de Baja California, México

Alma Maldonado Departamento de Investigaciones Educativas, Centro de Investigación y de Estudios Avanzados, México

Alejandro Márquez Jiménez Instituto de Investigaciones sobre la Universidad y la Educación, UNAM México

José Felipe Martínez Fernández University of California Los Angeles, USA
Fanni Muñoz Pontificia Universidad Católica de Perú

Imanol Ordorika Instituto de Investigaciones Economicas - UNAM, México

Maria Cristina Parra Sandoval Universidad de Zulia, Venezuela

Miguel A. Pereyra Universidad de Granada, España

Monica Pini Universidad Nacional de San Martín, Argentina

Paula Razquin UNESCO, Francia

Ignacio Rivas Flores Universidad de Málaga, España

Daniel Schugurensky Universidad de Toronto-Ontario Institute of Studies in Education, Canadá

Orlando Pulido Chaves Universidad Pedagógica Nacional, Colombia

José Gregorio Rodríguez Universidad Nacional de Colombia

Miriam Rodríguez Vargas Universidad Autónoma de Tamaulipas, México

Mario Rueda Beltrán Instituto de Investigaciones sobre la Universidad y la Educación, UNAM México

José Luis San Fabián Maroto Universidad de Oviedo, España

Yengny Marisol Silva Laya Universidad Iberoamericana, México

Aida Terrón Bañuelos Universidad de Oviedo, España

Jurjo Torres Santomé Universidad de la Coruña, España

Antoni Verger Planells University of Amsterdam, Holanda

Mario Yapu Universidad Para la Investigación Estratégica, Bolivia 


\section{arquivos analíticos de políticas educativas conselho editorial}

Editor: Gustavo E. Fischman (Arizona State University)

Editores Associados: Rosa Maria Bueno Fisher e Luis A. Gandin

(Universidade Federal do Rio Grande do Sul)

Dalila Andrade de Oliveira Universidade Federal de Minas Gerais, Brasil

Paulo Carrano Universidade Federal Fluminense, Brasil

Alicia Maria Catalano de Bonamino Pontificia Universidade Católica-Rio, Brasil

Fabiana de Amorim Marcello Universidade Luterana do Brasil, Canoas, Brasil

Alexandre Fernandez Vaz Universidade Federal de Santa Catarina, Brasil

Gaudêncio Frigotto Universidade do Estado do Rio de Janeiro, Brasil

Alfredo M Gomes Universidade Federal de Pernambuco, Brasil

Petronilha Beatriz Gonçalves e Silva Universidade Federal de São Carlos, Brasil

Nadja Herman Pontificia Universidade Católica -Rio Grande do Sul, Brasil

José Machado Pais Instituto de Ciências Sociais da Universidade de Lisboa, Portugal

Wenceslao Machado de Oliveira Jr. Universidade Estadual de Campinas, Brasil
Jefferson Mainardes Universidade Estadual de Ponta Grossa, Brasil

Luciano Mendes de Faria Filho Universidade Federal de Minas Gerais, Brasil

Lia Raquel Moreira Oliveira Universidade do Minho, Portugal

Belmira Oliveira Bueno Universidade de São Paulo, Brasil

António Teodoro Universidade Lusófona, Portugal

Pia L. Wong California State University Sacramento, U.S.A

Sandra Regina Sales Universidade Federal Rural do Rio de Janeiro, Brasil

Elba Siqueira Sá Barreto Fundação Carlos Chagas, Brasil

Manuela Terrasêca Universidade do Porto, Portugal

Robert Verhine Universidade Federal da Bahia, Brasil

Antônio A. S. Zuin Universidade Federal de São Carlos, Brasil 